\title{
FACING THE CHALLENGES OF COVID-19 IN THE EGYPTIAN BANKING SECTOR: THE ROLE OF BRICOLEURS IN ACHIEVING ORGANIZATIONAL INNOVATIONS VIA LEARNING THROUGH IMPROVISATION
}

(iD) Said Abdo ${ }^{1+}$
(iD) David Edgar
2

Article History

Received: 2 July 2021

Revised: 6 August 2021

Accepted: 30 August 202

Published: 20 September 2021

\section{Keywords}

Bricoleurs

Improvisation

COVID-19

Banking

Egypt

Innovation competences.

JEL Classification: O30 General, O31 Innovation and Invention: Processes and

Incentives.

\author{
'Associate Professor, School of Management, Modern University for \\ Technology \& Information (MTI), El-hadaba, El-Wosta, Mokatam, Cairo, \\ Egypt. \\ Email:Said.sayed@mgt.mti.edu.eg Tel:00201224629549 \\ ${ }^{2}$ Professor of Strategy and Business Transformation, Glasgow School for \\ Business and Society, Glasgow Caledonian University, Glasgow, Scotland. \\ Email:d.a.edgar@gcu.ac.ukTel:0044(o)1413313180
}

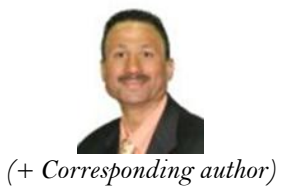

ABSTRACT

The COVID-19 pandemic posed many challenges for organizational survival across the world. Innovative capability became a key force in meeting such challenges and was most evident in Egypt's banking sector. This paper explores, through semi-structured in-depth interviews with six general managers of multinational banks operating in Egypt, what innovation competences may enable organizational improvisers, or bricoleurs, to challenge, change, and achieve innovation during the COVID-19 pandemic. The results were analyzed through the lens of Senge's five disciplines of learning organizations (Senge, 1990), with a particular consideration for the role of improvisation, and found that personal mastery is the dominant principle and is linked to achieving innovation in organizations. Within this element, the analysis also suggests that improvisation emerges from creativity, past experience, intuition, and distinct triggers, and that innovation competences appear as complementary elements of an organization's behavior, encapsulated as a form of bricolage when challenges arise and resource constraints prevail. The results suggest that a set of practices and strategies could be applied by general managers to meet the challenges they face involving constraints, such as a shortage of human resource, and that improvisation can form one of their key innovation competences.

Contribution/Originality: This study contributes to the existing literature by advancing the conversation on this topic through introducing the concept of the bricoleur as a vehicle to enhance innovative capability and introduce new and novel thinking to the challenges that banks face, as well as to the underpinning theory around Senge's learning organizations.

\section{INTRODUCTION}

A market environment that is open, challenging, malleable, ambiguous and, in general, complex, can result in continuous pressures of time which challenge traditional settings and calls for improvisation (Eisenhardt, 1997; Levallet \& Chan, 2013). Organizations that respond quickly can benefit from opportunities to achieve competitive advantage (Tanriverdi, Rai, \& Venkatraman, 2010), which, as Cunha \& Clegg (2019) would claim, "render[s] the capacity to learn especially valuable - hence the importance of the notion of the learning organization" (p. 238). In such unpredictable environments, pre-prepared plans often do not comply with the traditional perspective of 'doing' and improvisation is the alternative. Our paper explores this concept in the crisis of the COVID-19 pandemic. 
If companies want to achieve competitive advantage, they need to learn to change. Companies constantly evolve due to economic pressures and changing contexts (King, Watkins, \& Han, 2020) and recognize that they will not survive if they do not change (Watkins \& Marsick, 1993). This need for incessant change requires organizations to cultivate the capabilities to innovate in the present while keeping an eye on the future (Levallet \& Chan, 2013). In effect, they need to continuously learn and develop new competences.

There is strong evidence that competence is a strategic concept and the catalyst for lifelong learning and change management. This interrelates learning, training, work, and organizations (Sartori, Costantini, Ceschi, \& Tommasi, 2018) and can be defined in terms of personal characteristics comprising a cluster of knowledge, skills, and capabilities, which enable individuals to be effective in the workplace and in everyday life (Spencer \& Spencer, 1993).

Consequently, in an unpredictable environment, learning organizations are required to shape skills to adjust and overcome the consequences of change (Bokeno \& Gantt, 2000). Such learning is one of the constituents of improvisation and is an approach to meet the demands of resource scarcity and the need for immediate action. However, while concepts related to improvisation are often labeled as influences on the learning organization, this is a grossly under-researched area in the context of learning and innovation competences. Moreover, improvisation may sometimes be considered as a failure of control and is an impediment to learning, whereas, in fact, it allows learning to adjust to the environment (Reese, 2019). Thus, improvisation is regarded as a skill or a type of ability that can be, or should be, learned (Galbraith, 1990; Holdhus et al., 2016).

Accordingly, organizations and their leaders will be required to reinforce environments that react to changes by supporting continuous learning and reflection for individuals, groups, and teams by promoting a supportive culture that embraces customs, behaviors, and outlooks, and enabling employees to ask questions and frame discussions (King et al., 2020). Despite their key role in meeting the challenges of change in organizations, innovation skills seem to be relatively unexplored as moderating effects interlinking learning, improvisation, and innovations. Thus, the aim of this paper is to investigate what innovation competences may enable organizational improvisers, or bricoleurs, to challenge change and achieve innovation during times of crisis.

\section{LITERATURE REVIEW}

\subsection{Improvisation}

Improvisation has been defined as the "a spontaneous... unplanned and creative process of attempting to achieve an objective in a new way" (Vera \& Crossan, 2004). Performing by improvisation denotes that actions of the design, planning and execution stages seamlessly occur together, as illustrated in fields such as jazz, Indian music and music therapy (Moorman \& Miner, 1998). Vera \& Crossan (2005) offer six mutual constituents of effective improvisation that apply to both theatrical contexts and organizations: expertise, teamwork quality, a culture that tolerates mistakes, access to real-time information, strong communication, and training for skill building and increased use of improvisational performances.

These authors emphasize that organizational leaders can successfully learn the skill of improvisation and use it as a competence in the management of their organizations.

Since improvisation is not based on intuition, but is a skill that can be learned (Holdhus et al., 2016), it appears that improvisational skills and behaviors could be enriched by learning, and may in turn support individual creativity to foster organizational innovation in a fast changing and unpredictable environment. Our research aims to extend the understanding of how these innovation skills could support organizational leaders in achieving innovation in their organizations through the lens of the learning organizations' five disciplines process proposed by Senge (1990) in the context of the banking industry. 


\subsection{Motives and Benefits of Improvisation}

It has long been argued that formal planning procedures are inadequate for coping with unsettled environments (Burns \& Stalker, 1961) and that planning itself does not ensure market success. In fact, it may be deemed a waste of time and resources in such circumstances, bringing with it the danger of increasing the complexity within an already complex environment (Chelariu, Johnston, \& Young, 2002). In contrast, improvisation can support organizations to undergo the necessary metamorphosis in order to deal with unforeseen circumstances and may be an alternative to the formal planning perspective.

Accordingly, to respond to the limits of planning, organizations need to learn to develop the appropriate competences and skills to be open to their environment through improvisation (Cunha \& Clegg, 2019), for example, interruptions arising from market instability, problems with technology (Nuñez \& Lynn, 2012), a volatile environmental shock (Crossan, Lane, White, \& Klus, 1996), or crisis (Webb \& Chevreau, 2006).

Many benefits of improvisation have been identified in the existing literature. For instance, according to Edmondson (2008), improvisation is one of the key imperatives for enhancing organizational learning. It also supports people in becoming more effective in terms of their presence, flexibility, and communication skills, even in problematic circumstances (Hadida, Tarvainen, \& Rose, 2015). Moreover, as well as enabling people to execute specific actions better by routinizing successful additions, improvisation helps to support new product success (Akgün, Byrne, Lynn, \& Keskin, 2007).

As improvisation counteracts inaction and supports inquiry and reflection, it brings with it high levels of autonomy and can be considered as an exercise in mindfulness. In effect, once an improvisational competence is constructed, learning is fueled accordingly to achieve innovation (Cunha \& Clegg, 2019). Nevertheless, although improvisation offers the possibility of action that responds to both the immediate past and the present (Chelariu et al., 2002), the competences that enable improvisers to bring about the change needed to achieve innovations have not yet been fully explored. In addition, Liu, Lv, Ying, Arndt, \& Wei (2018) stated that "little is known about the conditions under which firms benefit from improvisation”. In this study, we seek to address these gaps.

\subsection{The Learning Organization}

As a response to an increasingly changeable business environment, the concept of the learning organization has been developed to address the need for companies to instill approaches for continuous improvement, thus achieving sustainable competitive advantage (Skyrme, 2010). The characteristics of a prosperous organization were assumed to comprise employee participation and trained and skilled workforces, together with flexibility and continuous learning (Hallam, Andrew, \& Rebecca, 2013). Improvisation improves the transfer of such existing learning mechanisms and skills to enhance others (Biasutti, 2017) by being open to the environment, improvising, and incorporating a wider scope of action (Cunha \& Clegg, 2019).

Senge (1990) described learning organizations as "organizations where people continually expand their capacity to create the results they truly desire, where new and expansive patterns of thinking are nurtured, where collective aspiration is set free, and where people are continually learning to learn together" (Senge, 1990). He classified five disciplines (see Figure 1) as a chain of principles and practices that support the learning organization, namely personal mastery, mental models, shared vision, team learning, and systems thinking. He stressed that, for an organization to learn, each of the five characteristics "must be in evidence" (Tait \& Blinco, 2014).

The dynamic potency of an organization is widely considered to rest in its people, whose personal mastery or skills constitute the chief discipline. Thus, an organization's capacity and commitment for learning can be no greater than that of its individual members-organizations learn only through the individuals that constitute them (Hallam et al., 2013; Senge, 1990). Acknowledging personal skills emphasizes that through each individual's comprehension the prosperity of the individual and organization are determined (Muh, Tahmir, \& Nawawi, 2016). Different perspectives are acknowledged, appreciated, and encouraged to nurture a stronger understanding of team 
synergy and forms of change throughout the organization, which can lead to the development of a shared vision tying every direction and motion of the entire organization together by a mutual ambition, creating a spark and level of excitement which lifts up the whole organization (Hallam et al., 2013).

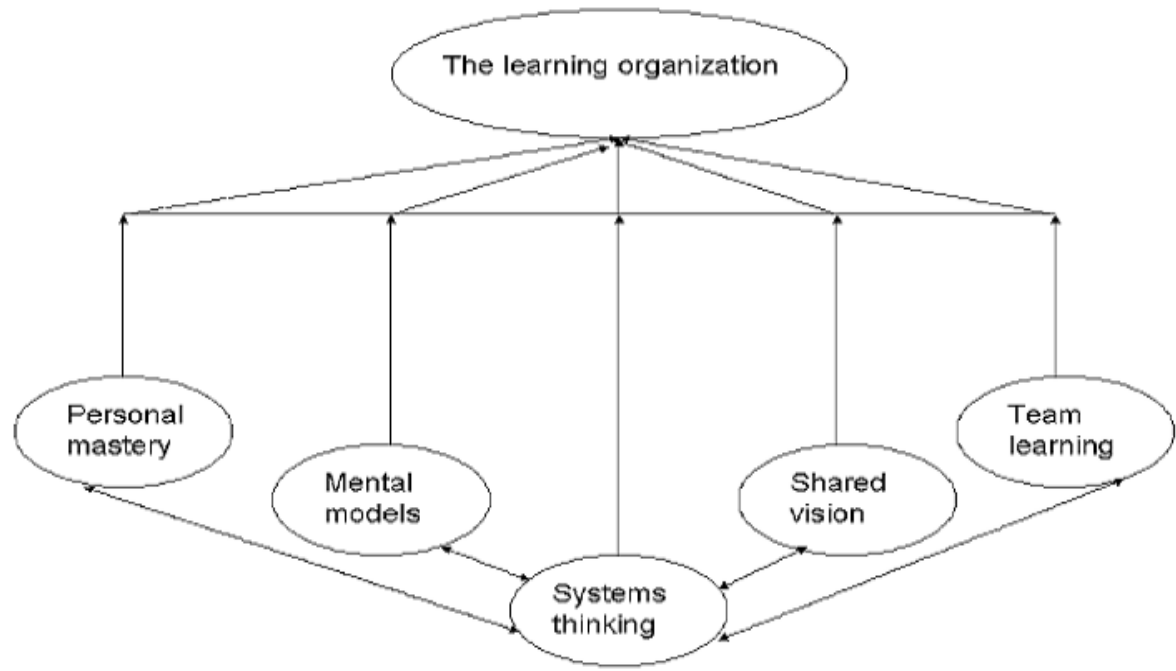

Figure 1. Senge's five disciplines of learning organizations.

This subsequently shapes the basis for team learning that begins with exchange of ideas and allows continuous learning and empowerment of the team members. Talented teams consist of skilled people and there is the capacity to achieve the mutual objectives through the orientation and development of the team's competences (Hallam et al., 2013). The fifth discipline is system thinking, which comprises the capability to perceive the dissimilarities of elements, assimilating them, and thus discovering unprecedented solutions for problems. Systems thinking comprises the whole framework of individual and organization lifestyles to think and act so that the organization can learn efficiently and productively (Muh et al., 2016). For organizations that wish to be learning organizations, these five disciplines should be pursued with desire (Jensen, 2017). Nevertheless, a fundamental concern is grounded by questioning in what way "learning processes of individuals and within organizations are working" (Luhn, 2016). Lindegaard \& Kawasaki (2010) stress the importance of involving people who are innovative leaders with organizational innovation capabilities to achieve innovation in their organizations in spite of the challenges they may encounter, e.g., resource availability, uncertainty, or differences in goals.

While Senge's work is well known and documented, there has not been any significant study that has empirically explored which of Senge's five principles is the most dominant, or which competences or capabilities best support improvisers and leaders to achieve innovation in their organization. We will seek to fill this knowledge gap in this study.

Earlier studies have accentuated the importance of bricolage, particularly for mobilizing resources when managers face resource constraints (Linna, 2013). In essence, bricolage is the requirement to make do with those materials that are to hand, as improvisation always necessitates quick responses to address unpredicted requirements (Lévi-Strauss, 1966). To date, no attention has been paid to which competences and skills support General Managers (GMs) of multinational enterprises (MNEs) as bricoleurs in the context of the banking industry in developing countries. Thus, this study uses the disruption caused by the COVID-19 crisis to investigate improvisation as a well-thought-out activity in a group of learning organizations, in this case multinational banks in the Egyptian context. 


\section{RESEARCH QUESTIONS}

The overarching aim of this study is to investigate what the innovation competences are that may enable organizational improvisers to face the challenges regarding the changes needed to achieve innovations using Senge's five disciplines of learning organizations as a theoretical framework.

In order to achieve this, the following research questions are addressed:

1. What are the characteristics of the multinational bank leaders operating in Egypt that enable them to be entitled as successful improvisers through the learning organization process?

2. How have the characteristics helped them to transform their organizations into a learning organization?

3. Which skills are being utilized by organizational leaders to cope with challenges in order to change their organizations to achieve innovation?

4. What is the dominant discipline out of Senge's five disciplines that acts as a catalyst for innovation skills and leaders' capabilities in organizations?

5. What were the triggers of improvisation, and which benefits did the leaders reap from improvisation that enabled them to achieve dominance in the market?

\section{CONCEPTUAL FRAMEWORK}

Organizational improvisation is still an under-researched phenomenon (Levallet \& Chan, 2013). It has been suggested that, due to its inherent characteristics, it is rarely captured in conceptual analyses of the learning organization "or discussed in the context of a learning organization as a structured activity" (Cunha \& Clegg, 2019). Improvisations happen when individuals "invent, slip into, or learn new ways of interpreting and experiencing the world" (Orlikowski, 2002), and as such, improvisation is temporary, unexpected, unpredictable and grounded in pure practice, comprising of endeavors to resolve a maze of possible subjects, clues and objectives that arise in the contexts of an organization's development and processes (Cunha \& Clegg, 2019).

Businesses continuously change, meaning that increasing importance rests on their capability to gather data, gain insights, and adapt at all levels, rather than operate in a mundane environment where there is a drawn out procedure written in a strategic plan instead of an agile daily journey built upon sound learning practices (Reese, 2019).

Senge's (1990) model of learning organizations has been considered seminal as organizations have used corporate learning for competitive advantage (King et al., 2020). The role of the model in prompting an organization's learning process has also been emphasized (Al Dousari, 2019). As such, Senge's (1990) model is a useful starting point to investigate which capabilities and skills underpin an extemporaneous process like improvisation.

An early study by Miner, Bassof, \& Moorman (2001) revealed links between improvisation and organizational learning, where stored knowledge and skills shape improvisation in important ways. However, their observations did not identify specific skills that support leaders in improvising to achieve innovation through the learning organization processes. Thus, one of the key emphases of the current research is to address this gap in the existing literature by exploring the underpinning the skills that support leaders in generating innovations in their organizations based on Senge's model.

The concept of competence, with emphasis on connectivity between individuals and work, has been used by scholars to characterize abilities at work, critical human knowledge, and attitudes (Sandberg, 2000). The expected criteria for individual competences are that they should be recognizable, measurable, and pertinent for practice (Caird, 1992). Competences can be learned, promoted, and designated at dissimilar levels, as well as being expected to contribute to the effectiveness of organizations (Prahalad \& Hamel, 1990).

In emphasizing the close rapport between improvisation and the learning organization, Weick (1998) claims that, although the idea of coordinated learning is obvious, the unexpected feature of improvisation is the way it 
combines strategies and activities in one fluid action where structure is also a source of learning. It has also been argued that, although learning and improvisation are profoundly entangled, little is understood regarding their reciprocal intertwining (Cunha \& Clegg, 2019; Miner \& O’Toole, 2018). Our research aims to explore the outcomes of the reciprocity between learning organizations and improvisation by determining what the supportive skills are that enable leaders to achieve innovation.

\section{METHOD}

\subsection{Research Method and Design}

This study aims to discover which innovation competences may enable organizational improvisers in multinational enterprises (MNEs) — in this case multinational banks operating in Egypt— to meet the challenges of change in achieving innovation. A qualitative approach was selected in the form of semi-structured interviews to gather primary data and life experiences, which, when analyzed though the lens of Senge's five disciplines of learning organizations, provide insight into the competences and improvisation practices of leadership. The data gathered via interviews enabled us to attain consistent and valid data, which was applicable to the research context, and explore a difficult to articulate phenomenon. The interviews were conducted in Arabic and were translated by the researcher and reverse translated for validity and reliability.

\subsection{Participants}

The interview participants were carefully selected to guarantee the significance of their knowledge and strategic roles in their multinational (MN) banks. Following the views of Yin (2018) and Thomas (2015), who suggest a population of no more than five to ten participants is suitable for qualitative research, we undertook six face-to-face interviews.

Table 1. Interviews with the general managers of multinational (MN) banks operating in Egypt.

\begin{tabular}{|c|c|c|c|c|c|c|c|c|c|}
\hline $\begin{array}{l}\text { No } \\
\text {. }\end{array}$ & $\begin{array}{l}\text { Nam } \\
\text { e }\end{array}$ & $\begin{array}{l}\text { Gende } \\
\mathbf{r}\end{array}$ & $\begin{array}{l}\text { Nationalit } \\
\mathrm{y}\end{array}$ & $\begin{array}{l}\text { Job } \\
\text { Titl } \\
\text { e }\end{array}$ & $\begin{array}{l}\text { Industr } \\
\mathrm{y}\end{array}$ & $\begin{array}{l}\text { Locatio } \\
\text { n }\end{array}$ & $\begin{array}{l}\text { Intervie } \\
\text { w } \\
\text { Duration }\end{array}$ & Profile & Additional Skills \\
\hline 1 & $\mathrm{SM}$ & Female & Egyptian & GM & Banking & Cairo & $\begin{array}{l}55 \\
\text { minutes }\end{array}$ & $\begin{array}{l}18 \text { years' } \\
\text { experienc } \\
\text { e in the } \\
\text { banking } \\
\text { industry }\end{array}$ & $\begin{array}{l}\text { English/French/numeracy } \\
\text { skills/leadership/research } \\
\text { skills }\end{array}$ \\
\hline 2 & WH & Male & Egyptian & GM & Banking & Cairo & $\begin{array}{l}61 \\
\text { minutes }\end{array}$ & $\begin{array}{l}20 \text { years' } \\
\text { experienc } \\
\text { e in the } \\
\text { banking } \\
\text { industry }\end{array}$ & $\begin{array}{l}\text { English/accounting } \\
\text { skills/leadership/many } \\
\text { certificates and awards in the } \\
\text { banking industry }\end{array}$ \\
\hline 3 & AY & Male & Egyptian & GM & Banking & Cairo & $\begin{array}{l}58 \\
\text { minutes }\end{array}$ & $\begin{array}{l}25 \text { years' } \\
\text { experienc } \\
\text { e in the } \\
\text { banking } \\
\text { industry }\end{array}$ & $\begin{array}{l}\text { English/accounting/comput } \\
\text { er literacy skills in the } \\
\text { banking industry }\end{array}$ \\
\hline 4 & TK & Male & Egyptian & GM & Banking & Cairo & $\begin{array}{l}52 \\
\text { minutes }\end{array}$ & $\begin{array}{l}15 \text { years' } \\
\text { experienc } \\
\text { e in the } \\
\text { banking } \\
\text { industry }\end{array}$ & $\begin{array}{l}\text { English/accounting/financia } \\
1 \text { analyst in the EGY stock } \\
\text { market in the banking } \\
\text { industry }\end{array}$ \\
\hline 5 & GN & Male & Egyptian & GM & Banking & Cairo & $\begin{array}{l}64 \\
\text { minutes }\end{array}$ & $\begin{array}{l}28 \text { years' } \\
\text { experienc } \\
\text { e in the } \\
\text { banking } \\
\text { industry }\end{array}$ & $\begin{array}{l}\text { English/accounting/financia } \\
1 \text { accredited consultant in the } \\
\text { banking industry }\end{array}$ \\
\hline 6 & $\mathrm{AD}$ & Male & Egyptian & GM & Banking & Cairo & $\begin{array}{l}57 \\
\text { minutes }\end{array}$ & $\begin{array}{l}30 \text { years' } \\
\text { experienc } \\
\text { e in the } \\
\text { banking } \\
\text { industry }\end{array}$ & $\begin{array}{l}\text { English/German/leadership } \\
\text { skills in the banking industry }\end{array}$ \\
\hline
\end{tabular}


The research participants were all General Managers, as illustrated in Table 1, and one from each bank was selected according to their insights within their organization. The interviews were conducted with a semistructured approach, allowing the interviewer to ask pre-determined questions while allowing an appropriate margin to ask additional questions regarding their responses and life experiences (Bryman \& Bell, 2015).

\subsection{Data Analysis}

A thematic analysis was used to explore innovation competences that might enable organizational improvisers to challenge the changes for achieving innovations in the MN banks operating in Egypt. The coding and analysis were done manually.

\section{FINDINGS AND DISCUSSION}

\subsection{Triggers of Improvised Innovation Throughout the COVID-19 Pandemic}

The COVID-19 pandemic has challenged the management of every organization to evaluate their organization and accountability at local, national, and global levels (Wiedner, Croft, \& McGivern, 2020). Recent literature regarding learning organizations and management has highlighted how the pandemic has provided an opportunity, and a responsibility, to consider the role of learning for businesses and managers (Hudecheck, Sirén, Grichnik, \& Wincent, 2020). As managers attempt to uphold services amid a shortage of resources, including human resources, this crisis has prompted improvised innovation as an effective reaction (Wiedner et al., 2020). For example, improvisation, learning, and new ideas were evident as effective moves that supported the National Health Service (NHS) during the early stages of the COVID-19 crisis (Wiedner et al., 2020).

The general managers of the MN banks operating in Egypt emphasized the role of the COVID-19 pandemic as an urgent trigger and stimulus for improvised innovation in their organizations, where prepared plans and determined strategies proved futile.

"We are in the period of COVID-19 where we have shortage of human resources in terms of employees in general, and female employees specifically, since the Egyptian governments only endorsed male employees to attend their jobs in rotations with a capacity of 50\%, while females are allowed to work only one or two days a week. I have to do something extraordinary by utilizing what our employees have learned of versatile skills in our bank to implement changes effectively." (WH).

"We are facing a shortage in human resources due to the restrictions imposed by the government to operate with only $50 \%$ of the overall workforce, restrictions in office hours, limits of cash withdraws, plus the crowding of our clients to complete their transactions. We have to think beyond our plans and predetermined strategies to come up with new ideas, creative solutions, and innovations.'(AD).

On one hand, the urgency of these challenges required quick, agile, and immediate responses and actions, and on the other hand, the unavailability or scarcity of resources stimulated and helped the generation of new ideas and solutions with what was available to improvise and innovate through the process of learning. This corroborates the findings of other academic contributions; for instance, according to Wiedner et al. (2020), the synchronicity of urgency and resource scarcity affects a secondary trigger of improvised innovation. As stated in the above quotes, general managers of banks also pointed out that, due to COVID-19 and the resource scarcity, they could not rely on their predetermined strategies and plans to respond to a crisis. These findings are in line with McGivern et al. (2018), who stated that "normal rules no longer apply" to respond to an urgent and critical situation. Thus, "when a plan fails, the form of making it happen leads to improvisation in practice of innovation' (Malucelli, Barbosa, \& Carvalho, 2019). Therefore, it can be concluded that the synchronicity of resource scarcity and urgency are new triggers and stimuli for new ideas and learning that supports improvisation for innovation in the case of $\mathrm{MN}$ banks operating in Egypt. 


\subsection{Learning via Previous Experience for Supporting Management Innovation}

Management innovation has to do with the modifications in the manner that executives establish strategies, motivate people, make decisions, and orchestrate activities (Hamel, 2006). This involves the "generation and implementation of a management practice, process, structure, or technique that is new to the state of the art and is intended to further organizational goals" (Birkinshaw, Hamel, \& Mol, 2008). Learning has been conceptualized as the process whereby knowledge is formed by the transformation of experience. It ensues wherever there is prior experience that can be instantaneously implemented (Baets \& Van der Linden, 2000), or as a practice, wherever behavior changes as a result of experience (Maples \& Webster, 1980).

Learning through managers' prior experience enables executives to create tactics to modify strategies in unprecedented ways instead of relying on traditional predetermined plans to improvise and innovate in their organizations. The greater the individual's managerial experience and knowledge, the stronger the effect (Amabile, 1998; Venkataraman, 1997). The General Managers of the multinational banks in this study accentuated the role of their prior career experience accumulated through the learning process. They believe that their experience enabled them to orchestrate and deploy their scarce resources in a way that fulfilled their organizations' needs and enabled them to generate ideas to respond quickly and with agility to changes occurring in their environments to achieve innovations and market dominance.

"I have accumulated global experience in banking industry over approximately 20 years. I have worked in other banks in Egypt and abroad, and my long-term experience has allowed me to deploy and orchestrate my employees in clusters according to their specialisms and areas of expertise.”(WH).

"My experience has taught me that the one who innovates and responds quickly to the changes of the market environment will dominate and excel." (TK).

"I have an accumulated global learning experience that has enabled me to look at our banks and deploy newly recruited candidates according to their areas of expertise." (AD).

The findings above support the conclusions of other studies. For instance, Shane (2000) concluded that previous research posited that educational background and work experience affect managers' ability to identify and exploit opportunities. In addition, drawing on experience from their environmental backgrounds will enable experienced managers to pursue innovation (Birkinshaw et al., 2008). The interviewees in the current study emphasized that their global workplace experience helped them to generate innovative ideas and know-how by capturing opportunities and responding quickly to change. This also corroborates other findings that international experience does increase innovation as a result of organizational learning (Thakur-Wernz \& Samant, 2019).

As people progress in any career, they need to be able to continue to learn from experience (Parsa, Yaacob, Parsa, \& Parsa, 2014). Thus, it is not surprising that learning via previous workplaces and global experience emerged as a key component that aided general managers in bringing about management innovation in the MN banks operating in Egypt.

\subsection{Improvisation for Organizational Innovation Through a Learning Organization}

Improvisation can be defined as the ability to create and implement unplanned international solutions in the face of problems or unexpected changes (Conforto, Rebentisch, \& Amaral, 2016). Improvisation has developed as a significant subject in business research, permitting executives the freedom to change according to evolving situations.

Fruitful improvisation may lead to innovation that intensifies an organization's overall success. Subsequently, knowledge acquired through such improvisation can be utilized in nurturing forthcoming organizational strategies, “combining the requirement with ongoing processual and procedural enhancements" (Malucelli et al., 2019). A learning organization will impact the incidence of improvisation and escalate the organization's mindfulness and awareness through learning when dealing with unforeseen situations (Kyriakopoulos, 2011). The general managers 
of the MN banks operating in Egypt declared that they had recourse for improvisation in order to respond to the challenges they were facing in the turbulent environment caused by COVID-19. This enabled them to achieve their aims and innovations in their organizations.

"Because of these challenges, I tried to break the rules and improvise and innovate in subtle ways. For instance, I do not follow the example of the Egyptian central bank by charging our clients high fees for keeping them running every three months, so I created a package of all-inclusive services with very low fees to achieve competitive advantage and sustainability." (SM).

"Due the circumstances cause by the Coronavirus, the challenges we faced, and the competitive environment that needed quick, creative and innovative responses, I opted to stick to the rules and traditional longstanding guidelines provided by the central bank of Egypt and improvised to innovate. I reduced cash transactions and permitted free transfers, I permitted double the amount of money that we would normally hold in our ATMs (automated teller machines), and I also improvised to innovate by opening the draft for 20000 EGP in our ATMs, which contradicted all the ATM allowance drafts across Egypt, which was 5000 EGP.” (WH).

These quotes are in line with the conclusions of other scholars; for instance, if there is high external turbulence in the environment, improvisation will constitute the overriding part in promoting innovation in organizations (Pavlou \& El Sawy, 2010). Thus, in times of pressure, spontaneous actions and creative innovation will be the optimal choice for managers to achieve their objectives. Managers interviewed in the current study also emphasized that they might initiate risks, such as defying the example set by the Central Bank, to meet their goals and continue to innovate. Irrespective of the challenges they face, this echoes the assertion that improvisation involves carrying on, regardless of challenges and risks, and fosters learning (Cunha \& Clegg, 2019). Improvisational activities turn out to be the prospective bases of learning when dealing with forthcoming circumstances; an improvising organization is a learning organization (Cunha \& Clegg, 2019).

\subsection{The Competences Buttressing Improvisation for Innovations: Creativity and Intuition}

Spontaneous organizational action is unavoidable in many situations and has prompted academic attention owing to its prospective value in stimulating organizational innovation (Pavlou \& El Sawy, 2010) and generating innovative competence (Hadida et al., 2015). Innovation competences are essential in organizational innovation, which is the process of converting ideas into products or services that satisfy customers' needs and wants. They have been identified as personal attributes that permit individuals to be effective in the changing circumstances of a place of work as well as in daily life (Sartori et al., 2018). Leybourne \& Kennedy (2015) suggest that improvisation ensues from creativity, intuition, and experience, as these constitute essential competences for leaders.

\subsubsection{Creativity}

Improvisation should include innovation and deviate in some way from prior plans or strategies (Moorman \& Miner, 1998). In this sense, improvisation has been entitled 'creative,' referring to the process that is aimed to engender novelty (Vera \& Crossan, 2005). However, the rapport between improvisation and creativity is indistinct in the current literature (Fisher \& Amabile, 2008).

In the interviews, the General Managers of these MNBs explained how they devoted their abilities and skills to improvise and innovate via creative and new ideas, products, and services to salvage their organizations.

"I'm keen to learn about every single detail of the financial market. I have to continuously learn which shares in the stock market plummet, and which rise, to obtain and provide accurate information and creative solutions to cope with the COVID-19 crisis in terms of increasing the number of clients and overcoming human resource constraints. I created a collateral cash system to allow my clients to withdraw cash against their assets and shares in our bank to invest this elsewhere to get double benefits. Without creativity you cannot excel in the market." (WH). 
"I always look outside the box for innovative and creative solutions for our clients; as a result, I have gained the trust of the Central Bank of Egypt, who chooses our bank, plus the CIB, Banque Misr, and The Arab Bank to set up the "BUS system" to reduce costs and accelerate our services, allowing our clients to easily make purchases with their cards internationally to alleviate crowding in our banks.”(SM).

"I like innovative and creative ideas to be implemented in my bank because they contribute to our prosperity regardless of whether they are in accordance with the rules set out by our headquarters. For instance, during COVID-19, I improvised and innovated by creating a hybrid of facilitating services for our clients by pausing the rules and taking risks by transferring large sums of money for our big clients using our transfer cars because people were afraid of coming to the bank in person for fear of becoming infected by the coronavirus." (GN).

These quotes illustrate how organizational creativity has been used ubiquitously and applied to services, innovative products, practices, or plans (Fisher \& Amabile, 2008). Thus, based on their creative mindsets and experiences they were able to convert resource constraints into innovations. This confirms the academic perspective that creativity is a mindset that permits people to engender ideas, apply new thinking, improve outdated ideas, and renew current ideas in an innovative way (Gallagher \& Gallagher, 1994). In addition, the interviewees stated that they abandoned their old tactics, traditional strategies, and ways of thinking and relied on creativity to solve the problems and challenges they encountered; this also corroborates other academic contributions. As Gardner (1994) points out, creativity is basically a way of solving problems. Moreover, the quotes illustrate how these creative people tend not to perceive things in their predetermined categories and are inclined to develop openness to experience competences (Rogers, 1961). Their behavior is also linked to personal mastery characteristics, where people who work creatively live a life from “a creative as opposed to a reactive viewpoint” (Senge, 1990). The above argument also strengthens the argument that creativity represents a particularly valuable competence for organizations' improvisation and innovation competences (Miner et al., 2001).

\section{Monitoring}

The dominant competency being exercised in the below accounts is monitoring competencies.

“... if a client, organization, factory owner, etc. possesses a large sum of money in their account, I get approval for an exception from our headquarters to give the customer the highest rates so that they remain with our bank and we retain their business. I am familiar with our big clients in person; I communicate with them personally on the phone, I monitor their needs and demands, I build close relationships with them, and I listen to their feedback and address any concerns or suggestions as appropriate in terms of new services, attitudes, products, etc." (SM).

"I monitor my employees closely; I help them, listen to them, and communicate with them via the internet and our intranet, Facebook, and WhatsApp to support them and pass on my wealth of experience and knowledge." (TK).

"At the end of every single day I monitor, review, and audit the sum of the transactions, total services, and products that have been used throughout the day. Monitoring is at the heart of our work; we are dealing with people's money and therefore we have to be vigilant and alert all the time." (WH).

This competency has been acknowledged in the literature and can be inferred in other academic studies. For instance, the monitoring competency has been related to individuals who evaluate and provide feedback on group and individual performances (Chatenier, Verstegen, Biemans, Mulder, \& Omta, 2010), accepts feedback regarding his/her performance, and gathers evidence of accomplishments (Sartori et al., 2018). This also refers to the personal mastery domain of learning, i.e., "the extent to which people see themselves as being in control of the forces that importantly affect their life” (Pearlin, Menaghan, \& Lieberman, 1981).

\section{Create a Learning Climate Competency}

A key attitude that the interviewees shared was their belief in openness as a foundation of a learning climate. 
"I like the open-door policy. I have to consider every single detail, monitor our employees and customers, be cautious with our services, keep an eye on other services provided by our competitors, and try to outperform them by renewing our services, sending management and employees on training courses, and attending seminars and conferences to develop our skills and knowledge and learn to apply this new knowledge to innovative services and products for our clients continuously." (SM).

"I do not believe in a workplace based on punitive and imperative actions. I strongly believe in harmonization, encouragement, and allowing for mistakes provided that we learn from them. We need to continuously learn new things from our financial providers, clients, counterparts, and even our market rivals, and we have to remain alert to avoid being outperformed." (GN).

The respondents emphasized that they rely on an open-door policy for dealing with their clients and staff, encouraging workshops, attending learning and training sessions, and tolerating mistakes to allow learning to prevail. In addition, they believe in developing relationships and networking among themselves and with their clients to facilitate innovations. This is aligned with the findings of other academics, such as Sartori et al. (2018), who came to the same conclusion that competences that enable managers to apply creativity and innovation are related to creating a learning environment individuals are allowed to make mistakes. They also observed that these managers develop, retain, and use effective networks, are accessible, maintain relationships and alliances, possess the ability to deal with unpredicted circumstances, and demonstrate flexibility and improvisation (ibid. p. 5). In the same vein, the interviewees of the current research illustrated other researchers' conclusions that champions of organizational innovations should have an inclusive depiction of their organizations and comprehend and manage complexity (Eoyang, 1997; Schweizer, 2006). Thus, monitoring and creating a skill-learning climate with clusters of innovation competences was the most prevalent among managers of MN banks operating in Egypt, and this enabled them to improvise through learning organization processes and activities.

\subsubsection{Intuition}

Intuition has been delineated as 'a cognitive conclusion based on the decision maker's previous experiences and emotional inputs' (Leybourne \& Sadler-Smith, 2006). Improvisation has been described as the capability to develop and execute unpremeditated solutions (Conforto et al., 2016) directed by unprompted intuition (Crossan \& Sorrenti, 1997). These definitions emphasize the role of experience and accumulated knowledge in supporting intuition and, in turn, assisting improvisation.

"When problems arise in my bank, I react spontaneously with the best solutions, as I have faced similar situations many times throughout my career." (AD).

"I teach my employees how to deal with our customers based on their nature, and how to recognize the emotional states of our clients who come into our banks." (TK).

In line with the above quotes, the General Managers of the MN banks operating in Egypt emphasized the role of intuition in terms of their previous experience and accumulated tacit knowledge and know-how that enabled them to come up with spontaneous solutions for problems arising within their organizations and orchestrate their employees based on their areas of expertise. This, in turn, enhanced learning and promoted improvisation for innovation in their banks. The findings of this research confirm the links among improvisation, learning, and intuition posited by Leybourne (2006) and Leybourne \& Kennedy (2015). They enabled their staff to 'learn’ the emotional status of bank clients via their senses only; this strengthens the conclusion that intuition is related to 'gut feelings' or reactions without rationale (Leybourne \& Sadler-Smith, 2006), as intuitive responses are based on previous experiences (Campbell, 1991).

Consequently, based on the above argument, it appears that learning from past experience, innovation competences (monitoring and creating a learning environment), intuition, and creativity are interconnected skills that underpin improvisation for innovations in organizations in the case of MNBs operating in Egypt. Previous 
authors (e.g., Malucelli et al., 2019) have stated that improvisation results from creativity, intuition and experience, which are essential skills for managers. The novelty of this research has been to explore those innovation competences as new pillars for improvisation for innovations.

\subsection{Bricolage to Overcome Resource Scarcity for Innovations}

Bricolage has been characterized as an approach to solving problems which appropriately utilizes opportunities by combining available resources (Baker \& Nelson, 2005). Innovating hinges not so much on finding ideal combinations of resources but rather enhancing jobs by using resources that are dispersed, unseen, and misused (Witell et al., 2017). Nevertheless, the process by which innovations arise from resource scarcity is still under scrutiny. This is where the concept of bricolage may be advantageous in comprehending innovation in a situation where resources are scarce (Linna, 2013). Bricolage is characterized by actions that propose or determine other courses of action when resources are scarce (Malucelli et al., 2019). Improvisation and bricolage are similar in the formation and execution of ideas and actions that happen together synchronically without prior planning and with little time to collect resources (Baker, Miner, \& Eesley, 2003). A bricoleur is someone who uses whatever is at hand', and this repertoire of resources can be odd and heterogeneous (Witell et al., 2017).

"I have had to look outside the box and not stick to things that were previously planned by orchestrating our existing employees to carry out multiple tasks simultaneously." (SM).

"I responded to this by using a variety of systems that were available to me without having to ask head office for additional funding because we were dealing with the COVID-19 crisis. These included an automated phone system, WhatsApp messages, e-transactions via our web service, and using personal email to handle our clients' various requirements and transactions." (WH).

"One employee carried out jobs that usually require two or three employees by acting in many functions and job positions." (AD).

"During the COVID-19 crisis, I created a hybrid of confidential ways to meet my clients' requirements and complete their transactions to overcome the shortage of human resources." (AY).

In the above quotes, the interviewees emphasized the utilization of their skills in facing the challenges brought about by COVID-19 and the shortage of human resources by orchestrating the deployment of employees' in a way that achieved their allocated tasks and served their clients appropriately as well as achieving innovations. This confirms the proposition that when an organization's workforce has insufficient employees with a particular competence, or they are not positioned in the right place or their competences have become obsolete, the ability of a bricoleur to deploy employees appropriately comes into play (Witell et al., 2017).

In addition, the interviewees emphasized the abilities of their competent staff to carry out many functions simultaneously to overcome the shortage of human resources due to the restrictions imposed by the government in an attempt to reduce the spread of COVID-19. This corroborates authors, such as Gibbert, Hoegl, \& Välikangas (2007), who argue that 'would-be innovators facing constraints are more likely to find creative analogies and combinations that would otherwise be hidden under a glut of resource.' As Lévi-Strauss (1966) pointed out, the 'bricoleur' is adept at performing a large number of diverse tasks.

The role of utilizing networks was also accentuated by the General Managers, who reported that they took advantage of network applications, such as WhatsApp, e-transactions and using the personal emails of their clients, to ease the burden of communication during the crisis period. This also confirms the necessity of the skill of networking with external partners to better cope with resource constraints (Perry, Chandler, \& Markova, 2012). Thus, it is recommended that organizations should nurture and develop bricolage skills to achieve innovations in their organizations, as this domain of learning is inextricably linked with organizational learning and innovation. 


\subsection{Personal Mastery as the Dominant Discipline of Senge's Five Disciplines}

Personal mastery relates to the capacity to understand reality as accurately as possible, personal commitment to explain and enroot a personal vision, the development of patience, and how to focus energy (Senge, 1990).

According to Senge et al. (2000), personal mastery is an array of practices that assist people in pursuing their dreams while promoting an awareness of the current reality.

"I created an environment of working as a well-bounded and communicative team by motivating and encouraging them. I always look outside of the box for innovative and creative solutions for our clients; confidentiality and commitment are the cornerstone of our work in banking industry." (SM).

"We are very committed to our values, principles, and we are responsible for the safety of our clients and employees in terms of implementing and practicing safety measures." (WH).

"Due to my awareness, anticipation, and being able to foresee circumstances in advance, we rely on our vision as the cornerstone of the financial market. We have to live for today but predict the needs of the future, and encourage and motivate our employees with free coffee, tea, and snacks to start with high spirits and a positive attitude." (WH).

"I manage my bank based on my goals; managing by achieving our goals is considered one of our strategic plans. I like to continuously learn and convey what I have newly learned to my employees, which, in turn, will be utilized among them." (GN).

These quotes from the General Managers of the MN banks operating in Egypt highlight the role of motivation as one of the activities in learning organizations. It has been argued that motivation and commitment are related to the personal mastery domain in the learning organization model proposed by Senge (1990). As a discipline practiced at the level of the individual in organizations, it reinforces "the personal motivation to continually learn how our actions affect our world" (Senge, 1990). The interviewees' insistence that they rely on their vision as the cornerstone of their work reflects Senge's argument that personal vision is the "groundwork" for constantly increasing personal mastery. For individuals with augmented levels of personal mastery, a vision is "a calling, not just a good idea, and behind their goals is a sense of purpose” (Bui \& Baruch, 2010).

The interviewees in the current study emphasized their commitment to learning via attending learning sessions, workshops, and seminars in Egypt and overseas to transfer what they have learned to their staff and to promote innovation. This corroborates the conclusions of other academic studies that the personal mastery discipline is individual learning, where individuals are the primary learning entities enabling organizational transformation (Dodgson, 1993), and continuous employee learning is closely related to personal mastery (Bui \& Baruch, 2010). Thus, it appears that personal mastery is the dominant principle out of Senge's five principles of learning organization in MNBs operating in Egypt.

\section{CONCLUSION}

This research represents one of the first endeavors to empirically investigate what the innovation competences are that could help General Managers of MN bank operating in Egypt. The aim of this research has been addressed by proposing the theoretical framework presented in Figure 2.

Building on Senge's learning organization model of the five principles of a learning organization, this research offers an integrated framework, which differs from Senge's model, as it illustrates personal mastery as the dominant component above the other four phases of learning organizations. It also clarifies that personal mastery represents not merely a person's characteristics, rather it supports and fosters other domains such as triggers of improvisation, past experience, improvisation activities via the learning process, and the tripartite competences (creativity, innovation, and intuition) that support improvisation for innovation. Overall, personal mastery fosters the capability of bricoleurs to convert all these competences into innovations. The current research indicates that, in a time of crisis and challenges, certain domains of Senge's learning organization model may take precedence over 
others, requiring solo doers who can orchestrate and master resource constraints in an effective and efficient way to achieve innovations in their organizations.

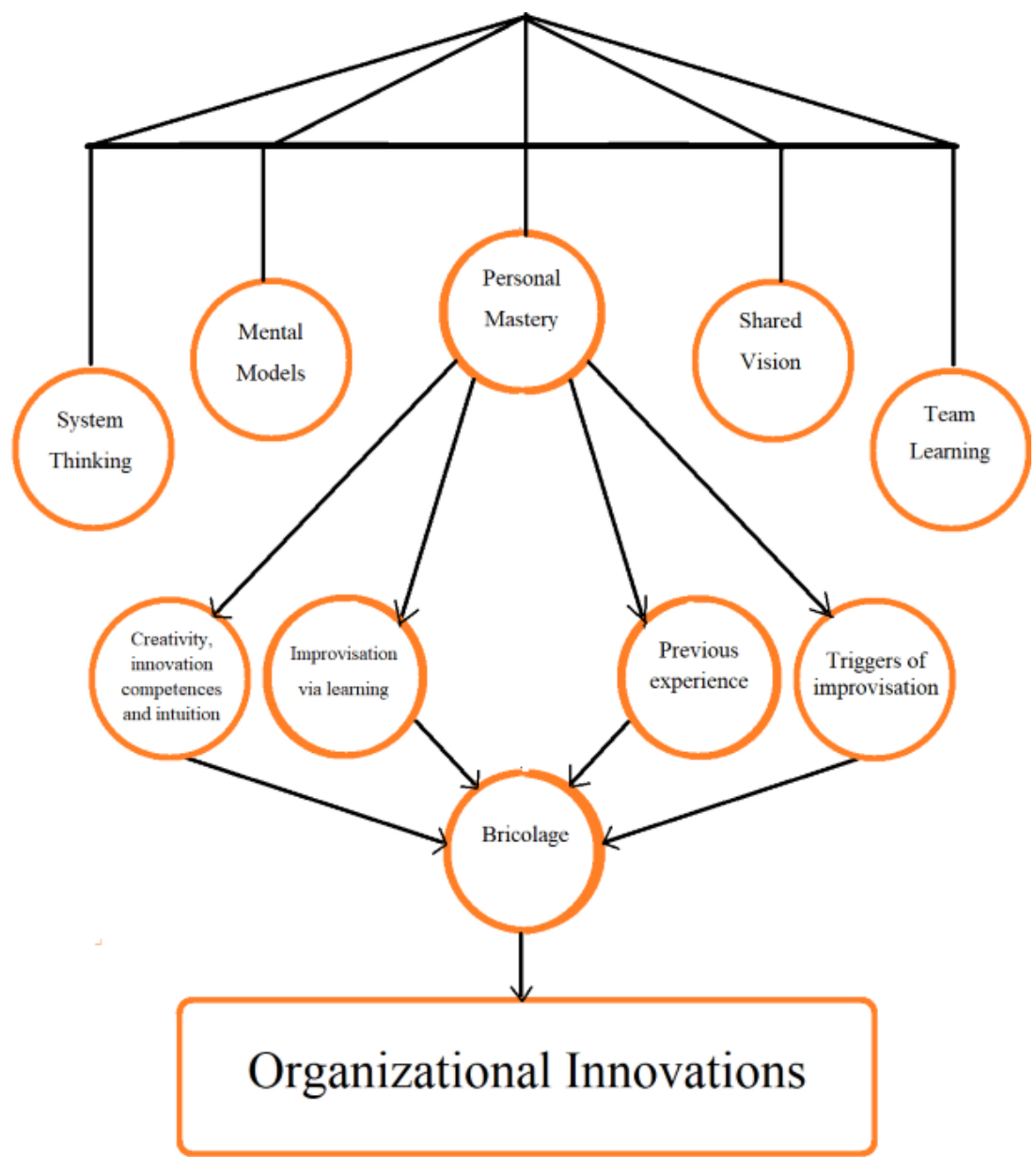

Figure 2. Competences that enable bricoleurs to innovate.

The current research also suggests that personal mastery not only proliferates from creativity, intuition, and experience, but also from innovation competences in which personal mastery acts as a catalyst and a new moderator that links these competences to actual innovations in an organization once raised to the bricolage stage. Bricolage emerged as a way of thinking, and bricoleurs emerged as individuals with an indispensable mindset that can orchestrate and deploy available resources effectively to achieve innovations in organizations. The results showed how the General Managers of the MN banks operating in Egypt achieved market dominance, customer loyalty and satisfaction, technological innovations, and skills to orchestrate resource as benefits from improvisation in their organizations.

At the center of the managerial implications that arise from the proposed framework is the illumination of what is essential to successfully enhance learning organization activities. According to the proposed framework, executives can investigate the degree to which their MNBs can transform into learning organizations and the alternative ways to achieve this. The suggested framework proposes concerns for executives to consider in order to be titled bricoleurs for achieving innovations in their organization through learning.

\section{LIMITATIONS AND RECOMMENDATIONS FOR FUTURE RESEARCH}

While we have moved the conversation forward around the concepts of improvisation and learning organizations, the findings of our study are not essentially generalizable to all banks operating in Egypt or even to all General Managers of these banks. 
The interviewees who participated in the research responded to questions that targeted a general manager's perceptions and practices. However, multinational banks comprise various stakeholders, including vice-managers, administrative staff, and shareholders. Thus, findings resulting from the General Managers' perceptions are narrow and, while significant and interesting, do not apply in all contexts. As such, we propose a conceptual framework that requires further examination empirically in governmental and agricultural banks, and the results compared and contrasted.

Future research is needed to examine the association between learning organization activities both during and after the COVID-19 crisis, which may yield different results. In addition, due to the COVID-19 crisis, time constraints, busy interviewees, crowded banks, safety measures, and resource constraints, only a small number of banks participated. Therefore, future research needs to be conducted on a larger sample of multinational banks with different research instruments to yield more reliable conclusions. Replication of the current research with different financial services or contexts might also be productive.

Funding: This study received no specific financial support.

Competing Interests: The authors declare that they have no competing interests.

Acknowledgement: Both authors contributed equally to the conception and design of the study.

\section{REFERENCES}

Akgün, A. E., Byrne, J. C., Lynn, G. S., \& Keskin, H. (2007). Organizational unlearning as changes in beliefs and routines in organizations. Journal of Organizational Change Management, 20(6), 794-812. Available at: https://doi.org/10.1108/09534810710831028.

Al Dousari, S. F. (2019). Impact of process oriented business culture in transforming organizational performance: A case of Texaco. International Journal of Business and Management, 14(7), 124. Available at: https://doi.org/10.5539/ijbm.v14n7p124.

Amabile, T. M. (1998). How to kill creativity (Vol. 87). Boston, MA: Harvard Business School Publishing.

Baets, W., \& Van der Linden, G. (2000). The hybrid business school: developing knowledge management through management learning. Amsterdam: Prentice Hall.

Baker, T., Miner, A., \& Eesley, D. (2003). Improvising firms: Bricolage, account giving, and improvisational competency in the founding process. Research Policy, 32(3), 255-276. Available at: https://doi.org/10.1016/s0048-7333(02)00099-9.

Baker, T., \& Nelson, R. E. (2005). Creating something from nothing: Resource construction through entrepreneurial bricolage. Administrative Science Quarterly, 50(3), 329-366. Available at: https://doi.org/10.2 189/asqu.2005.50.3.329.

Biasutti, M. (2017). Teaching improvisation through processes. Applications in music education and implications for general education. Frontiers in Psychology, 8, 911. Available at: https://doi.org/10.3389/fpsyg.2017.00911.

Birkinshaw, J., Hamel, G., \& Mol, M. J. (2008). Management innovation. Academy of Management Review, 33(4), 825-845.

Bokeno, R. M., \& Gantt, V. W. (2000). Dialogic mentoring: Core relationships for organizational learning. Management Communication Quarterly, 14(2), 237-270. Available at: https://doi.org/10.1177/0893318900142002.

Bryman, A., \& Bell, E. (2015). Ethical principles. In: Fourth, ed. Business Research Methods (pp. 134-145). Oxford: Oxford.

Bui, H., \& Baruch, Y. (2010). Creating learning organizations: A systems perspective. The Learning Organization, $17(3)$, $208-227$. Available at: https://doi.org/10.1108/09696471011034928.

Burns, T., \& Stalker, G. M. (1961). The management of innovation. London: Tavistock.

Caird, S. (1992). Problems with the identification of enterprise competencies and the implications for assessment and development. Management Education and Development, 23(1), 6-17. Available at: https://doi.org/10.1177/135050769202300110.

Campbell, B. J. (1991). Planning for a student learning style. Journal of Education for Business, 66(6), $356-359$. 
Chatenier, E. D., Verstegen, J. A., Biemans, H. J., Mulder, M., \& Omta, O. S. F. (2010). Identification of competencies for professionals in open innovation teams. RED Management, 4O(3), 271-280. Available at: https://doi.org/10.1111/j.1467-9310.2010.00590.x.

Chelariu, C., Johnston, W. J., \& Young, L. (2002). Learning to improvise, improvising to learn: A process of responding to complex environments. Journal of Business Research, 55(2), 141-147. Available at: https://doi.org/10.1016/so1482963(00)00149-1.

Conforto, E. C., Rebentisch, E., \& Amaral, D. (2016). Learning the art of business improvisation. MIT Sloan Management Reviere, $57(3), 8-10$.

Crossan, M., \& Sorrenti, M. (1997). Making sense of improvisation. In Walsh, J.P. and Huff, A.S. (Eds.), Advances in Strategic Management (Vol. 14, pp. 155-180). Greenwich, CT: JAI Press.

Crossan, M. M., Lane, H., White, R. E., \& Klus, L. (1996). The improvising organization: Where planning meets opportunity. Organizational Dynamics, 24(4), 20-35. Available at: https://doi.org/10.1016/s0090-2616(96)90011-x.

Cunha, M., \& Clegg, S. (2019). Improvisation in the learning organization: A defense of the infra-ordinary. Learning Organization, 26(3), 238-251. Available at: https://doi.org/10.1108/tlo-07-2018-0126.

Dodgson, M. (1993). Organizational learning: A review of some literatures. Organizational Studies, 14(3), 375- 394. Available at: https://doi.org/10.1177/017084069301400303.

Edmondson, A. C. (2008). The competitive imperative of learning. Harvard Business Review, 86(4), 60-67. Available at: https://doi.org/10.1109/emr.2014.6966928.

Eisenhardt, K. M. (1997). Strategic decision making as improvisation. In: Papadakis V., Barwise P. (eds) Strategic Decisions. Boston, MA: Springer

Eoyang, G. H. (1997). Coping with chaos: Seven simple tools. Minnesota: Lagumo.

Fisher, C. M., \& Amabile, T. (2008). Creativity, improvisation and organizations The Routledge companion to creativity (pp. 27-38): Routledge.

Galbraith, C. S. (1990). Transferring core manufacturing technologies in high-technology firms. California Management Review, 32(4), 56-70. Available at: https://doi.org/10.2307/41166628.

Gallagher, J. J., \& Gallagher, S. A. (1994). Teaching the gifted child (4th ed.). Needham Heights, MA: Allyn and Bacon.

Gardner, H. (1994). Creating minds. New York: Basic Books.

Gibbert, M., Hoegl, M., \& Välikangas, L. (2007). In praise of resource constraints. MIT Sloan Management Review, 48(3), 15.

Hadida, A. L., Tarvainen, W., \& Rose, J. (2015). Organizational improvisation: A consolidating review and framework. International Journal of Management Reviews, 17(4), 437-459. Available at: https://doi.org/10.1111/ijmr.12047.

Hallam, G., Andrew, H., \& Rebecca, O. (2013). Conceptualising the learning organisation: Creating a maturity framework to develop a shared understanding of the library's role in learning and literacy. Paper presented at the International Federation of Library Associations and Institutions for the World Library International Conference, Singapore, Malaysia, July 15.

Hamel, G. (2006). The why, what, and how of management innovation. Harvard Business Review, 84(2), 72-83.

Holdhus, K., Høisæter, S., Mæland, K., Vangsnes, V., Engelsen, K. S., Espeland, M., \& Espeland, Å. (2016). Improvisation in teaching and education - roots and applications. Cogent Education, 3(1), 1204142. Available at: https://doi.org/10.1080/2331186x.2016.1204142.

Hudecheck, M., Sirén, C., Grichnik, D., \& Wincent, J. (2020). How companies can respond to the Coronavirus. MIT Sloan Management Review. Retrieved from: https://sloanreview.mit.edu/article/how-companies-can-respond-to-thecoronavirus/.

Jensen, J. D. (2017). The learning organization: A strategic approach to today's global business environment. The Journal of International Management Studies, 12(1), 55-66.

King, S. A., Watkins, K. E., \& Han, S.-H. (2020). From silos to solutions: How one district is building a culture of collaboration and learning between school principals and central office leaders. European Journal of Education, 55(1), 58-75. Available at: https://doi.org/10.1111/ejed.12382. 
Kyriakopoulos, K. (2011). Improvisation in product innovation: The contingent role of market information sources and memory types. Organization Studies, 32(8), 1051-1078. Available at: https://doi.org/10.1177/017084061 1410833.

Levallet, N., \& Chan, Y. E. (2013). The role of information systems in organizational improvisation: A perspective based on two complementary theories. Paper presented at the Proceedings of the Americas Conference on Information Systems, AIS, Chicago, IL.

Lévi-Strauss, C. (1966). The savage mind. Chicago: University of Chicago Press.

Leybourne, S. (2006). Managing change by abandoning planning and embracing improvisation. Journal of General Management, 31(3), 11-29. Available at: https://doi.org/10.1177/030630700603100302.

Leybourne, S., \& Kennedy, M. (2015). Learning to improvise, or improvising to learn: Knowledge generation and 'Innovative Practice' in project environments. Knowledge and Process Management, 22(1), 1-10.

Leybourne, S., \& Sadler-Smith, E. (2006). The role of intuition and improvisation in project management. International Journal of Project Management, 24(6), 483-492. Available at: https://doi.org/10.1016/j.ijproman.2006.03.007.

Lindegaard, S., \& Kawasaki, G. (2010). The open innovation revolution. Essentials, roadblocks, and leadership skills. London: Wiley.

Linna, P. (2013). Bricolage as a means of innovating in a resource-scarce environment: A study of innovator-entrepreneurs at the BOP. Journal of Developmental Entrepreneurship, 18(03), 1350015. Available at: https://doi.org/10.1142/s1084946713500155.

Liu, Y., Lv, D., Ying, Y., Arndt, F., \& Wei, J. (2018). Improvisation for innovation: The contingent role of resource and structural factors in explaining innovation capability. Technovation, 74, 32-41. Available at: https://doi.org/10.1016/j.technovation.2018.02.010.

Luhn, A. (2016). The learning organization. Creative and Knowledge Society, 6(1), 1-13.

Malucelli, G., Barbosa, M. T., \& Carvalho, M. M. (2019). Facing the challenge of improvisation in project management: A critical review. International Journal of Managing Projects in Business, 14(2), 369-389. Available at: https://doi.org/10.1108/ijmpb-02-2019-0038.

Maples, M. F., \& Webster, J. M. (1980). Thorndike’s connectionism. In G. Gazda \& R. Corsini (Eds.), Theories of learning (pp. 128). Itasca, IL: Peacock.

McGivern, G., Dopson, S., Ferlie, E., Fischer, M., Fitzgerald, L., Ledger, J., \& Bennett, C. (2018). The silent politics of temporal work: A case study of a management consultancy project to redesign public health care. Organization Studies, 39(8), 1007-1030. Available at: https://doi.org/10.1177/0170840617708004.

Miner, A. S., Bassof, P., \& Moorman, C. (2001). Organizational improvisation and learning: A field study. Administrative Science Quarterly, 46(2), 304-337. Available at: https://doi.org/10.2307/2667089.

Miner, A. S., \& O'Toole, J. (2018). Organizational learning and organizational improvisation. In Argote, L. and Levine, J. (Eds.), Handbook of Group and Organizational Learning. Oxford: Oxford University Press.

Moorman, C., \& Miner, A. S. (1998). The convergence of planning and execution: Improvisation in new product development. Journal of Marketing, 62(3), 1-20. Available at: https://doi.org/10.1177/002224299806200301.

Muh, S. M., Tahmir, S., \& Nawawi, J. (2016). Learning organization models. Mediterranean Journal of Social Sciences, 7(2 S1), 172.

Nuñez, E., \& Lynn, G. (2012). The impact of adding improvisation to sequential NPD processes on cost: The moderating effects of turbulence. Academy of Marketing Studies Journal, 16(1), 1-18.

Orlikowski, W. J. (2002). Knowing in practice: Enacting a collective capability in distributed organizing. Organization Science, 13(3), 249-273. Available at: https://doi.org/10.1287/orsc.13.3.249.2776.

Parsa, N., Yaacob, S. N., Parsa, P., \& Parsa, B. (2014). Effects of inter-parental conflict on college student's self-efficacy in Hamadan, Iran. Procedia-Social and Behavioral Sciences, 152, 241-245. Available at: https://doi.org/10.1016/j.sbspro.2014.09.187.

Pavlou, P. A., \& El Sawy, O. A. (2010). The "third hand": IT-enabled competitive advantage in turbulence through improvisational capabilities. Information Systems Research, 21(3), 443-471. Available at: https://doi.org/10.1287/isre.1100.0280. 
Pearlin, L. I., Menaghan, E. G., \& Lieberman, M. A. (1981). The stress process. Journal of Health and Social Behavior, 22(4), 337356.

Perry, J. T., Chandler, G. N., \& Markova, G. (2012). Entrepreneurial effectuation: A review and suggestions for future research. Entrepreneurship Theory and Practice, 36(4), 837-861. Available at: https://doi.org/10.1111/j.1540-6520.2010.00435.x.

Prahalad, C. K., \& Hamel, G. (1990). The core competence of the corporation. Harvard Business Review, 68(3), 79-91.

Reese, S. (2019). The practitioner's steps in making the learning organizational adaptive to the environment. The Learning Organization, 26(3), 319-322. Available at: https://doi.org/10.1108/TLO-04-2019-227.

Rogers, C. (1961). On becoming a person. Boston, MA: Houghton Mifflin Company.

Sandberg, J. (2000). Understanding human competence at work: An interpretative approach. Academy of Management Journal, 43(1), 9-25. Available at: https://doi.org/10.2307/1556383.

Sartori, R., Costantini, A., Ceschi, A., \& Tommasi, F. (2018). How do you manage change in organizations? Training, development, innovation, and their relationships. Frontiers in Psychology, 9, 313 . Available at: https://doi.org/10.3389/fpsyg.2018.00313.

Schweizer, T. S. (2006). The psychology of novelty-seeking, creativity and innovation: Neurocognitive aspects within a workpsychological perspective. Creativity and Innovation Management, 15(2), 164-172. Available at: https://doi.org/10.1111/j.1467-8691.2006.00383.x.

Senge, P., Cambron-McCabe, N., Lucas, T., Smith, B., Dutton, J., \& Kleiner, A. (2000). A fifth discipline resource: Schools that learn. A Fifth Discipline Fieldbook for Educators, Parents, and Everyone Who Cares About Education.

Senge, P. M. (1990). The fifth discipline the art and practice of the learning organization. Sydney: Random House Australia.

Senge, P. M. (2006). The fifth discipline: The art and practice of the learning organization: Currency.

Shane, S. (2000). Prior knowledge and the discovery of entrepreneurial opportunities. Organization Science, 11(4), 448-469. Available at: https://doi.org/10.1287/orsc.11.4.448.14602.

Skyrme, D. J. (2010). Knowledge management: Making sense of an oxymoron. Management Insight, 2 nd series, no 2.

Spencer, L. M., \& Spencer, S. M. (1993). Competence at work: A model for superior performance. New York: Wiley.

Tait, A., \& Blinco, K. (2014). Seeding a learning organisation. The Australian Library Journal, 63(2), 94-107. Available at: https://doi.org/10.1080/00049670.2014.903831.

Tanriverdi, H., Rai, A., \& Venkatraman, N. (2010). Research commentary—reframing the dominant quests of information systems strategy research for complex adaptive business systems. Information Systems Research, 21(4), 822-834. Available at: https://doi.org/10.1287/isre.1100.0317.

Thakur-Wernz, P., \& Samant, S. (2019). Relationship between international experience and innovation performance: The importance of organizational learning for EMNE s. Global Strategy Journal, 9(3), 378-404. Available at: https://doi.org/10.1002/gsj.1183.

Thomas, S. (2015). Exploring strategies for retaining information technology professionals: A case study. Doctoral Dissertation. Available from ProQuest Dissertations and Theses Database. (UMI No. 3681815)

Venkataraman, S. (1997). The distinctive domain of entrepreneurship research. In Advances in entrepreneurship, firm emergence and growth (Vol. 3, pp. 119-138): JAI Press Inc.

Vera, D., \& Crossan, M. (2004). Theatrical improvisation: Lessons for organizations. Organization Studies, 25(5), 727-749. Available at: https://doi.org/10.1177/0170840604042412.

Vera, D., \& Crossan, M. (2005). Improvisation and innovative performance in teams. Organization Science, 16(3), 203-224. Available at: https://doi.org/10.1287/orsc.1050.0126.

Watkins, K. E., \& Marsick, V. J. (1993). Sculpting the learning organization: Lessons in the art and science of systemic change. San Francisco: Jossey-Bass.

Webb, G. R., \& Chevreau, F.-R. (2006). Planning to improvise: The importance of creativity and flexibility in crisis response. International Journal of Emergency Management, 3(1), 66-72. Available at: https://doi.org/10.1504/ijem.2006.010282. 
Weick, K. E. (1998). Introductory essay-improvisation as a mindset for organizational analysis. Organization Science, 9(5), 543555. Available at: https://doi.org/10.1287/orsc.9.5.543.

Wiedner, R., Croft, C., \& McGivern, G. (2020). Improvisation during a crisis: Hidden innovation in healthcare systems. BMJ Leader, leader-2020.

Witell, L., Gebauer, H., Jaakkola, E., Hammedi, W., Patricio, L., \& Perks, H. (2017). A bricolage perspective on service innovation. Journal of Business Research, 79, 290-298. Available at: https://doi.org/10.1016/j.jbusres.2017.03.021.

Yin, R. K. (2018). Case study research and applications: Design and methods (6th ed.). Los Angeles, CA: Sage.

The views and opinions expressed in this article are the views and opinions of the author(s). The Journal of Social Economics Research shall not be responsible or answerable for any loss, damage or liability caused in relation to/arising from the use of the content. 